\title{
Foraging habitat and food intake of satellite-tracked king penguins during the austral summer at Crozet Archipelago
}

\author{
C. A. Bost ${ }^{1, *}$, J. Y. Georges ${ }^{2}$, C. Guinet ${ }^{2}$, Y. Cherel $^{2}$, K. Pütz ${ }^{3}$, J. B. Charrassin $^{1}$, \\ Y. Handrich ${ }^{1}$, T. Zorn ${ }^{1}$, J. Lage ${ }^{1}$, Y. Le Maho ${ }^{1}$ \\ 'Centre d'Ecologie et de Physiologie Energétiques, Centre National de la Recherche Scientifique, 23 rue Becquerel, \\ F-67087 Strasbourg, France \\ ${ }^{2}$ Centre d'Etudes Biologiques de Chizé, Centre National de la Recherche Scientifique, F-79360 Beauvoir sur Niort, France \\ ${ }^{3}$ Institut für Meereskunde an der Universität Kiel, Düsternbrooker Weg 20, D-24105 Kiel, Germany
}

\begin{abstract}
The relationships between the foraging strategy of seabirds, hydrographic features and food availability are poorly understood. We investigated the movements at sea, time spent per oceanic sector, food intake, and diet of king penguins Aptenodytes patagonicus in the Crozet Islands (Southern Indian Ocean) during summer, as a function of the position of major frontal zones. Fifteen trips at sea were monitored using satellite transmitters over 3 austral summers (1992 to 1994). During each season, satellite transmitters were used in conjunction with stomach temperature recorders in order to investigate feeding activity. The at-sea distribution of king penguins was closely related to the localisation of major hydrographic frontal systems. Intense prospectung areas were observed mainly in zones corresponding to the northern limit of the Polar Front $\left(50^{\circ}\right.$ to $51^{\circ}$ S), southern limit of the Sub-Antarctic Front $\left(44.50^{\circ}\right.$ to $\left.45^{\circ} \mathrm{S}\right)$, and a zone between $47^{\circ}$ and $48^{\circ} \mathrm{S}$. During trips directed south, 2 distinct phases based on travelling speed were detected. The myctophids Electrona carlsbergi, Krefftichtys anderssoni and Protomyctophum tenisoni dominated the diet. The estimated average amount of food ingested per day at sea was $2.4 \mathrm{~kg}$. Between 17 and $64 \mathrm{~kg}$ of food was captured during 7 to $25 \mathrm{~d}$ at sea. Approximately $80 \%$ of the food intake occurred during the first phase of the trip. Food intake was related to trip duration and relative amount of time spent in particular oceanic sectors. The sections $47^{\circ}$ to $48^{\circ} \mathrm{S}$ and $48.5^{\circ}$ to $50.50^{\circ} \mathrm{S}$ appeared particularly favorable for food intake, the latter coinciding with the northern limit of the Polar Front. King penguins fed intensively on several distinct patches when traveling towards the Polar Front. The foraging range seems to be related to the foraging success during the first phase of the trip. The foraging strategy of king penguins during the summer favors displacements toward frontal zones where food availability is optimal.
\end{abstract}

KEY WORDS: Biotelemetry Foraging K King penguins Frontal zones Mesopelagic fishes Southern Ocean

\section{INTRODUCTION}

Penguins are major components of the Southern Ocean ecosystems (Croxall \& Prince 1987). Their large populations, wide distribution, and high energy demands play a fundamental role in the dynamics of marine resources. Consequently, there has been considerable interest over the last few years in studying

•E-mail: bost@c-strasbourg.fr their foraging strategy and their use of the ocean. These studies have become possible thanks to the development of microprocessor-based time-depth recorders (e.g. Kooyman et al. 1992, Chappell et al. 1993, Croxall et al. 1993, Wilson et al. 1994), satellite transmitters (Ancel et al. 1992, Davis \& Miller 1992, Jouventin et al. 1994), and recorders measuring feeding times and ingested masses (Wilson et al. 1992, Pütz \& Bost 1994). However, the relationships between the foraging strategy of penguins, food availability and oceanographic conditions remain poorly investigated. 
The aim of this work was therefore to study the movements at sea and the feeding activity of king penguins Aptenodytes patagonicus at the Crozet Islands in relation to the hydrographic features of the foraging areas and the ecology of the main prey, myctophid fish. The Crozet Islands area, in the southwest part of the Indian Ocean, is particularly favourable for this kind of study. Indeed, 3 major frontal zones come together in this area according to a north-south transect: the Transition Frontal Zone between $40^{\circ}$ and $43^{\circ} \mathrm{S}$, the Sub-Antarctic Front $\left(43^{\circ} \mathrm{S}\right)$, the Polar Frontal Zone, where Crozet is situated, and the Polar Front, localized in April at about $50^{\circ} 50^{\prime} \mathrm{S}$ (Park et al. 1991). These various frontal zones contribute in an important way to the primary and secondary production of the Southern Ocean (Lutjeharms 1985, El Sayed 1988). The Antarctic Polar Frontal Zone and the Polar Front have also been discovered to be a privileged area of concentration for many species of myctophid fish (Sabourenkov 1991) The distribution of myctophids, which form the most important biomass of mesopelagic fishes of the Southern Ocean (Bekker \& Evseenko 1987), still remains largely unknown.

One of the main predators of myctophids is the king penguin, for which $90 \%$ of the ingested biomass is myctophids (Cherel \& Ridoux 1992). With about 890000 pairs of king penguins, the Crozet Islands have the world's largest population of this species and an annual consumption rate of myctophids estimated to be about 745000 t (Guinet et al. 1996).

This paper constitutes the second part of a 3 year. study of the foraging ecology of the king penguin in the Crozet Islands during summer based on the satellite tracking of breeding birds. In the first part of the project, the objective was to examine the characteristics of their movements at sea relative to the distribution of the temperature of the sea surface obtained by satellite telemetry (Guinet et al. 1997, accompanying paper). In the present study, the objective was to examine at the same time the relationship among time spent in each oceanic sector, diet composition and masses of food ingested in relation to prey ecology. One of the aims was to check the assumption of Jouventin et al. (1994) that the 'long tracks' towards the Polar Front enable king penguins to obtain abundant feeding resources that are highly predictable. The present work is the first study to investigate the foraging activity of penguins fitted at the same time with satellite transmitters giving the positions at sea, and stomach recorders estimating the frequencies and mass of food ingestion. It also shows the potential of studies of penguin feeding ecology to provide information on the availability and distribution of oceanic resources.

\section{MATERIAL AND METHODS}

The study was carried out on Possession Island (46.42 $2^{\circ}, 51.90^{\circ} \mathrm{E}$. Crozet Archipelago) during 3 consecutive summer seasons (1992 to 1994). About 100000 pairs of king penguins breed on Possession Island, in 6 colonies of 450 to 41000 pairs (Weimerskirch et al. 1992)

Fifteen trips at sea of incubating or brooding king penguins were successfully monitored by satellite tracking for the present study (see Table 1). The penguins were fitted with PTTs (platform transmitter terminals; Toyocom 2038 transmitters) with a transmission interval of $90 \mathrm{~s}$ and either a continuous emission or an on-off interval of $12 \mathrm{~h}$. The transmitters, with cables ties attached to a small grid glued to the feathers of the back, had a cylindrical form and weighed $208 \mathrm{~g}$. In 1994, the fronts of the transmitters were hydrodynamically shaped to limit the drag resulting from the cross section of the device $\left(7 \mathrm{~cm}^{2}\right)$. In 1992 and 1993, 7 PTTs were deployed on birds breeding in a small colony located to the east of Possession Island (Chaloupe colony, 750 pairs). In February 1994, 4 PTTs were deployed on birds of the same colony and 4 on birds breeding $13 \mathrm{~km}$ away in the largest colony, in the north of the island (Jardin Japonais colony, 40000 pairs).

How the location data provided by the Argos system were used is described in Guinet et al. (1997). The relative use of the oceanic sectors was calculated and plotted by using Weavers' (1992) hypothesis. Thus, king penguins were assumed to move in a straight line and at a constant speed between 2 successive locations. Employing a $0.1^{\circ} \times 0.1^{\circ} \mathrm{grid}$ (approximately $7.7 \times 11.1 \mathrm{~km}$ ), several computer programs were used to estimate the relative amount of time spent in each $0.1^{\circ} \times 0.1^{\circ}$ pixel during time at sea (programs written by $\mathrm{V}$. and $\mathrm{J}$. Klinger and $\mathrm{C}$. Sidot). For each trip, we determined a 'threshold' amount of time corresponding to the median of the time spent per pixel. The $0.1^{\circ} \times 0.1^{\circ}$ areas prospected for a larger period than this value were defined as 'slowing down areas'. The corresponding amounts of time were defined as 'slowing down periods'. A 3-dimensional representation was then superimposed. over the trip at sea. The application of the method allowed us to estimate the relative amount of time spent per area for each bird as well as for all birds and for each year.

For the estimation of the feeding rate and mass of prey ingested, we used temperature logging units that recorded temperature changes within the stomach (Wilson et al. 1992, Pütz \& Bost 1994). Each logger (SICUP, Driesen-Kern, Bad Bramstedt, Germany) was enclosed in a titanium housing and recovered by 
stomach flushing The measurement interval was programmed to be $16 \mathrm{~s}$, with a maximum recording duration of $24 \mathrm{~d}$. After ingestion of prey at sea a characteristic temperature drop occurs, followed by an approximately exponential rise as the ingesta is warmed to normal body temperature. Estimation of feeding times and mass of ingesta are given in Wilson et al. (1992, 1995). Locations of feeds were calculated by interpolation of the time between the times given for the preceding and following position locations given by Argos. The database was assembled by a program which plotted the beginning and the end of feeding events (program written by C. P Doncaster, University of Oxford, UK). By dividing the amount of food ingested by the time spent in each latitude section of the trip, we provided an index of foraging effort close to the catch per unit effort index (CPUE) determined by Wilson et al. (1994), which allows indirect estimation of the existence of prey patches.

To determine the effect of the back-mounted transmitter on the feeding activity, the ingestion activity of fitted birds was compared in 1994 with 3 control birds without attached transmitter and induced to swallow a stomach temperature recorder The birds fitted with transmitters fed less often during the day (from dawn to dusk) than the control birds (with respectively 70.2 and $80 \%$ of the feeding events during the day; $\chi 1^{2}=15.22, p<0.001$ ). Although no breeding failure occurred, the mean duration of trips was $50 \%$ longer for the birds with transmitters compared with uninstrumented birds of the same colony monitored daily for the same period (respectively $9.9 \pm 1.7 \mathrm{~d}, \mathrm{n}=7$ and $6.0 \pm 1.7 \mathrm{~d}, \mathrm{n}=22$; Student's t-test $=4.19, \mathrm{p}<0.003$ ).

Diet analyses were performed on stomach contents sampled using the water off-loading technique (Wilson 1.984). In 1993, the samples were recovered from the full stomach contents of 10 penguins without transmitters, which had foraged at sea during the same period as the instrumented penguins. In 1994, stomach contents were recovered only from birds with transmitters. Determination and quantification of the main prey were made with the method described by Cherel \& Ridoux (1992). A total of 5734 prey items was recorded. Unidentified prey items contributed a negligible amount $(2.8 \%$ by number $)$.

Statistics were calculated from Sokal \& Rohlf (1981), Siegel \& Castellan (1988), Zar (1984), or LOGITHEQ. We used nested (hierarchical) analysis of variance (ANOVA) (Zar 1984) to compare inter-year variation of time spent at sea in relation with factor 'latitude', factor 'birds tracked' being nested within factor 'year' Significance was assumed for $\mathrm{p}<0.05$. Means are given $\pm \mathrm{SD}$.

\section{RESULTS}

\section{Foraging habitats during summer}

Relief maps with $0.1^{\circ} \times 0.1^{\circ}$ grid squares show the relative use of the prospected surface for the 3 years of study (Fig 1). Generally, the time spent at sea corresponded to 2 main sectors, situated to the southeast (from $46.50^{\circ}$ to $51.50^{\circ} \mathrm{S}$ and from $51^{\circ}$ to $54.70^{\circ} \mathrm{E}$ ), and the east of Crozet (from $44.50^{\circ}$ to $48^{\circ} \mathrm{S}$ and from $51.50^{\circ}$ to $55^{\circ} \mathrm{E}$; Fig. 1). These 2 main sectors could be related to the 2 main orientations observed for king penguin foraging trips, 1 towards the east $(n=3)$ and 1 towards the south $(n=11)$; the latter track was taken more than any other No difference in trip orientation (eastward or southward) was observed for the different years (Fig. 1a, b, c) or in the location of the study colony (east or north of Possession Island).

During the 3 summer periods, all of the instrumented penguins foraged in an area from $44.50^{\circ}$ to $51.50^{\circ} \mathrm{S}$ and from 51 to $56^{\circ}$ E, totaling $207264 \mathrm{~km}^{2}$ (2425 grid squares), with maximum foraging ranges varying between 264 and $558 \mathrm{~km}$ (Table 1).

Of the time at sea, $54 \%$ was spent in an area representing only $16.5 \%\left(34198 \mathrm{~km}^{2}\right)$ of the total surface prospected. This area was located along a line oriented south-east from Crozet, beginning at Possession Island, $46.42^{\circ} \mathrm{S}, 51.90^{\circ} \mathrm{E}$, and ending at $50.50^{\circ} \mathrm{S}$, $54.50^{\circ}$ E (Fig. 1 ).

\section{Eastward trips}

\section{Amount of time spent in the foraging area}

For the trips directed towards the east, the penguins spent much more time than expected at the northeastern limit of the trip, i.e. in a restricted part of the foraging range. Thus, $64 \%$ of the slowing down periods was concentrated in the sector between $55^{\circ}$ and $56^{\circ} \mathrm{E}$ in 1992 (longitude range: $51.50^{\circ}$ to $56^{\circ} \mathrm{E}, \chi_{1}{ }^{2}=7.0, \mathrm{p}<$ 0.01 , Fig 1a), $59 \%$ in the sector between $53.50^{\circ}$ and $54^{\circ} \mathrm{E}$ in 1993 (longitude range: $51.50^{\circ}$ to $55^{\circ} \mathrm{E}, \chi_{1}{ }^{2}=$ 8.34, $\mathrm{p}<0.01$, Fig 1b), and $40 \%$ in the sector between $54.50^{\circ}$ and $55.50^{\circ} \mathrm{E}$ in 1994 (longitude range: $51.50^{\circ}$ to $55.50^{\circ} \mathrm{E}, \chi_{1}^{2}=8.6$, Fig. $\left.1 \mathrm{C}\right)$

\section{Organisation of the foraging trip}

During eastward trips, no distinct phase could be extracted from the changes in traveling speed. Between the point of departure from the colony and the farthest point reached the speed did not differ significantly between the outward-and inward-bound journeys (respectively $2.95 \pm 1.81 \mathrm{~km} \mathrm{~h}^{-1}$ for going, $\mathrm{n}=114$, and $3.48 \pm 2.28 \mathrm{~km} \mathrm{~h}^{-1}$ for returning, $\mathrm{n}=12$, MannWhitney $U$-test, $U=488$, not significant). 
(a)
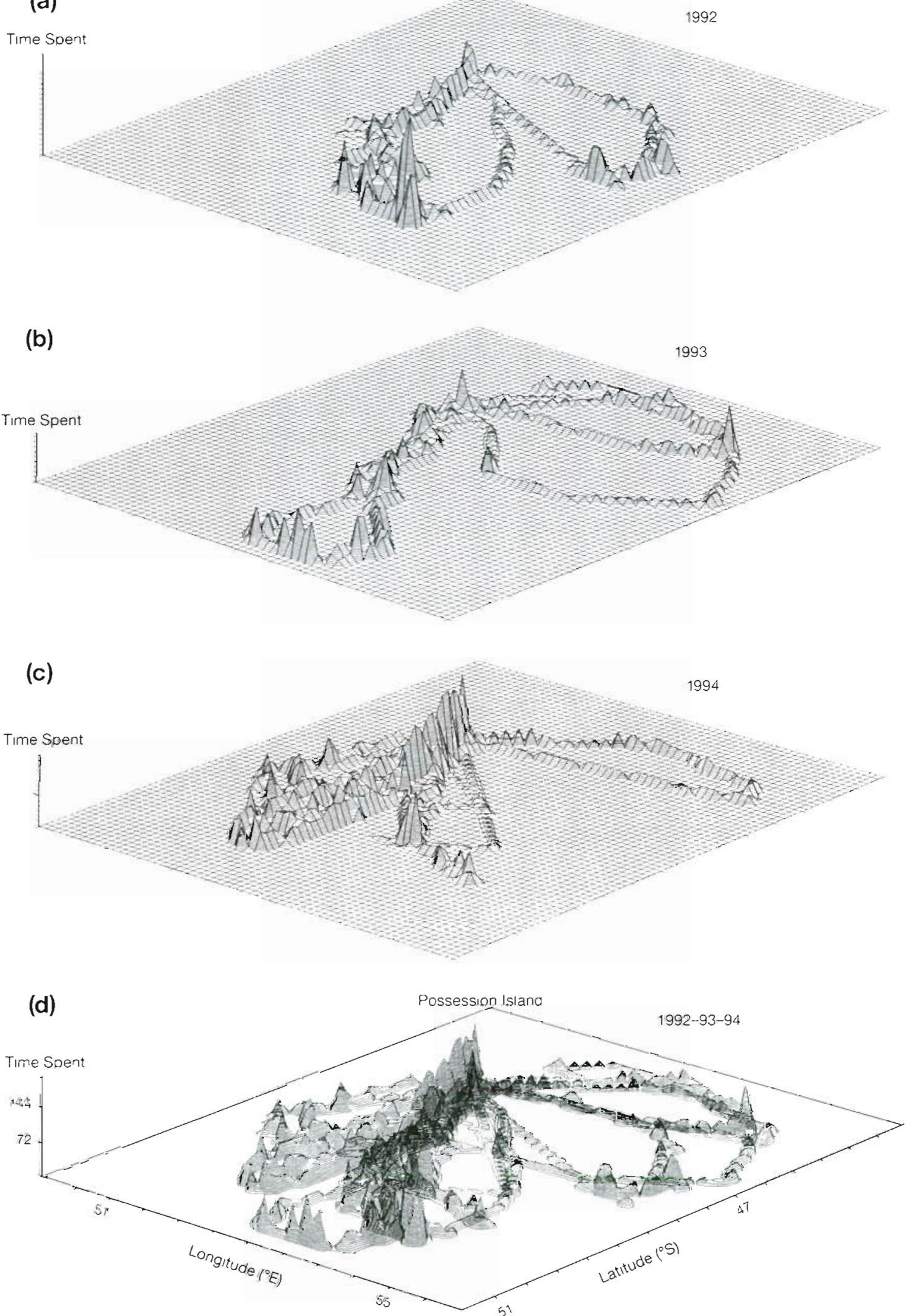

Fig 1 Amount of time spent by king penguins in a $0.1^{\circ} \times 0.1^{\circ}$ grid around Possession Island (Crozet Archipelago) in the summers of (a) 1992. (b) 1993. (c) 1994 and (d) the 3 years pooled. Each unit of the vertical contours corresponds to 30 min 
Table 1. Duration of trip, number of locations obtained by satellite tracking, maximum foraging range, mean speed of movement and time spent at sea for king penguins tracked during the summers of 1992 to 1994

\begin{tabular}{|c|c|c|c|c|c|c|c|c|c|c|}
\hline \multirow{2}{*}{$\begin{array}{l}\text { Bird } \\
\text { no. }\end{array}$} & \multirow{2}{*}{$\begin{array}{l}\text { Breeding } \\
\text { status }^{\mathrm{c}}\end{array}$} & \multirow{2}{*}{$\begin{array}{l}\text { Duration } \\
\text { of trip }\end{array}$} & \multirow{2}{*}{$\begin{array}{l}\text { No. of } \\
\text { locations }\end{array}$} & \multirow{2}{*}{\multicolumn{2}{|c|}{$\begin{array}{l}\text { Maximum foraging range } \\
\text { Distance Coordinates } \\
\text { (km) }\end{array}$}} & \multicolumn{2}{|c|}{ Speed $\left(\mathrm{km} \mathrm{h}^{-1}\right)^{\mathrm{b}}$} & \multicolumn{3}{|c|}{ Time spent at sea } \\
\hline & & & & & & Phase 1 & Phase 2 & $\begin{array}{l}\text { Total time } \\
\text { (h) }\end{array}$ & $\begin{array}{l}\text { Slowing } d \\
\text { (h) }\end{array}$ & $\begin{array}{l}\text { down periods } \\
\% \text { of total }\end{array}$ \\
\hline 1051 & 1 & $3-23 \operatorname{Jan} ' 92$ & 54 & 440 & $50.20^{\circ} \mathrm{S}, 53.58^{\circ} \mathrm{E}$ & $3.2 \pm 1.9$ & $3.0 \pm 1.3$ & 481.1 & 278.4 & 57.9 \\
\hline 1176 & 1 & $2-24 \operatorname{Jan}^{\prime} 92$ & 90 & 487 & $50.43^{\circ} \mathrm{S}, 54.48^{\circ} \mathrm{E}$ & $1.8 \pm 1.5$ & $3.6 \pm 1.3$ & 550 & 258 & 46.9 \\
\hline 1177 & 1 & $8-22 \operatorname{Jan} 92$ & 74 & 323 & $48.01^{\circ} \mathrm{S}, 55.42^{\circ} \mathrm{E}$ & - & - & 341 & 173 & 50.7 \\
\hline $2850-1$ & 2 & 25 Jan -3 Feb '93 & 34 & 316 & $49.13^{\circ} \mathrm{S}, 53.10^{\circ} \mathrm{E}$ & $2.9 \pm 2.4$ & $3.2 \pm 1.4$ & 242 & 166.7 & 68.9 \\
\hline 2852 & 1 & 25 Jan - 12 Feb '93 & 38 & 264 & $45.36^{\circ} \mathrm{S}, 54.91^{\circ} \mathrm{E}$ & - & - & 280.8 & 143 & 50.9 \\
\hline 2854 & 1 & $17-28 \operatorname{Jan} 93$ & 33 & 312 & $46.84^{\circ} \mathrm{S}, 55.90^{\circ} \mathrm{E}$ & _- & - & 283.8 & 144 & 50.7 \\
\hline 2855 & 1 & 27 Jan -4 Feb '93 & 117 & 558 & $51.28^{\circ} \mathrm{S}, 53.83^{\circ} \mathrm{E}$ & $1.9 \pm 1.1$ & $3.3 \pm 1.3$ & 613 & 313 & 51.1 \\
\hline $238-1$ & 2 & $4-16$ Feb ' 94 & 47 & 428 & $49.77^{\circ} \mathrm{S}, 54.74^{\circ} \mathrm{E}$ & $3.2 \pm 2.3$ & $3.2 \pm 2.3$ & 270.1 & 120.1 & 44.4 \\
\hline $238-2$ & 1 & 21 Feb-2 Mar 94 & 29 & 304 & $49.15^{\circ} \mathrm{S}, 52.26^{\circ} \mathrm{E}$ & $2.8 \pm 2.3$ & $3.5 \pm 1.3$ & 210.8 & 91.3 & 43.3 \\
\hline $239-1$ & 1 & 5-19 Feb'94 & 49 & 405 & $50.07^{\circ} \mathrm{S}, 51.81^{\circ} \mathrm{E}$ & $3.7 \pm 2.7$ & $5.9 \pm 3.3$ & 354 & 174.5 & 49.3 \\
\hline $240-1$ & 2 & $7-16$ Feb '94 & 37 & 318 & $49.21^{\circ} \mathrm{S}, 51.35^{\circ} \mathrm{E}$ & $3.0 \pm 1.7$ & $4.1 \pm 2.9$ & 224.2 & 84.8 & 37.8 \\
\hline $240-2$ & 2 & $18-28$ Feb ' 94 & 38 & 397 & $49.91^{\circ} \mathrm{S}, 52.30^{\circ} \mathrm{E}$ & $2.8 \pm 1.9$ & $2.8 \pm 1.3$ & 279.3 & 130.2 & 46.6 \\
\hline $315-1$ & 1 & $4-28$ Feb'94 & 21 & 456 & $50.52^{\circ} \mathrm{S}, 52.18^{\circ} \mathrm{E}$ & $1.6 \pm 0.7$ & $2.5 \pm 0.7$ & 583.8 & 309 & 52.9 \\
\hline $316-1$ & 2 & $8-18$ Feb'94 & 19 & 295 & $45.72^{\circ} \mathrm{S}, 55.43^{\circ} \mathrm{E}$ & - & - & 277.2 & 123.1 & 44.4 \\
\hline $316-2$ & 2 & $20 \mathrm{Feb}-2 \mathrm{Mar}^{\prime} 94$ & 24 & 356 & $49.30^{\circ} \mathrm{S}, 53.60^{\circ} \mathrm{E}$ & $2.4 \pm 0.8$ & $3.3 \pm 0.6$ & 291.5 & 147.1 & 50.4 \\
\hline $\begin{array}{l}{ }^{a} \text { Breedt } \\
{ }^{\mathrm{D}} \text { Two p } \\
\text { Phase } \\
\text { the lat } \\
\text { directe }\end{array}$ & $\begin{array}{l}\text { ng status o } \\
\text { hases coul } \\
1 \text {, from the } \\
\text { est location } \\
\text { ed towards }\end{array}$ & $\begin{array}{l}\text { of the birds studied: } \\
\text { uld be extracted for } \\
\text { he colony to the lates } \\
\text { on back to the colon } \\
\text { s the east }\end{array}$ & $\begin{array}{l}1 \text {, incuba } \\
\text { I the sout } \\
\text { st location } \\
\text { No. No suc }\end{array}$ & $\begin{array}{l}\text { ng; } 2, \text { brood } \\
\text { ward trips } \\
\text { correspond } \\
\text { distinction }\end{array}$ & $\begin{array}{l}\text { ding or last incubo } \\
\text { (see text) accord } \\
\text { ling to a speed inf } \\
\text { was possible for }\end{array}$ & $\begin{array}{l}\text { ion trip } \\
\text { ig to the } \\
\text { rior to the } \\
\text { ird nos. } 11\end{array}$ & $\begin{array}{l}\text { changes } \\
\text { average } \\
177,285\end{array}$ & $\begin{array}{l}\text { traveling } \\
\text { he whole t } \\
354 \text { and } 31\end{array}$ & $\begin{array}{l}\text { speeds of } \\
\text { trip; and PH } \\
16-1 \text {, whose }\end{array}$ & $\begin{array}{l}\text { individuals: } \\
\text { hase } 2, \text { from } \\
\text { se trips were }\end{array}$ \\
\hline
\end{tabular}

\section{Southward trips}

Amount of time spent in the foraging area

If one considers only the tracks in the sectors south of Possession Island, about $63 \%$ of the time at sea was spent on a line oriented southeast from the island, a total of 450 grid squares. Inter-year comparison of the time spent by the penguins at sea at the different latitudes showed a significant difference both between 1992 and 1993 (nested ANOVA, $F_{1,4}=9.6, p<0.05$ ) and between 1993 and 1994 (nested ANOVA, $F_{1,4}=$
12.4, $p<0.05$ ) (Fig. 2). Slowing down periods were observed on a scale of approximately $20 \mathrm{n}$ miles (Fig. 2). Most of these periods were recorded at the southern limit of the trips in all 3 years. In 1992, there was a high peak of time spent in the sector between $50^{\circ}$ and $50.50^{\circ} \mathrm{S}$, constituting $33 \%$ of the slowing down periods. In 1993, the sector between $50.50^{\circ}$ to $51.50^{\circ} \mathrm{S}$ included more than $20 \%$ of the periods, whereas in 1994 the periods principally occurred in the sectors between $47^{\circ}$ and $48^{\circ} \mathrm{S}$ and between $48.50^{\circ}$ and $50^{\circ} \mathrm{S}$, which together had $63 \%$ of the total (Fig. 2).
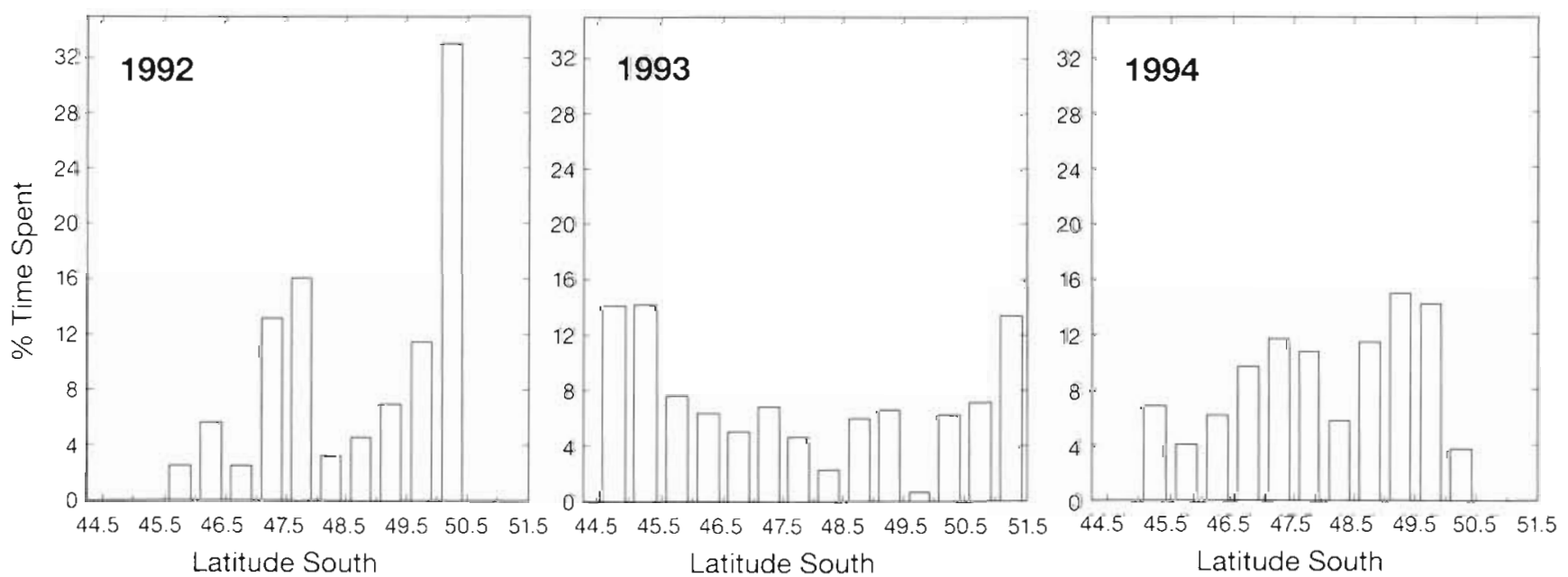

Fig. 2. Proportion of time spent in lowing down periods (see 'Methods') by foraging king penguins on southward trips per $0.5^{\circ}$ latitude section during the summers of (a) 1992, (b), 1993 and (c) 1994 


\section{Organisation of the foraging trip}

During southward trips, 2 distinct phases of individual traveling speed were distinguishable. The first phase was from the colony to the latest location, corresponding to a speed inferior to the average over the whole trip. The second phase was from that latest location back to the colony. The second phase always began distinctly from the farthest point from the colony. The speed during the first phase was less than the second (respectively $2.47 \pm 2.09 \mathrm{~km} \mathrm{~h}^{-1}, \mathrm{n}=175$, and $2.92 \pm 0.95 \mathrm{~km} \mathrm{~h}^{-1}, \mathrm{n}=12 ;$ Mann-Whitney $U$-test, $U$ $=631, \mathrm{p}<0.05$ ) and presented a larger variability (Fisher test, Sokal \& Rohlf 1981, FC $=4.84 \mathrm{~km} \mathrm{~h}^{-1}, \mathrm{p}<$ $0.05)$. Most of the slowing down periods occurred during the first phase of the trip rather than the second (respectively $13.2 \pm 6.20$ and $1.50 \pm 1.6$ periods, $\mathrm{p}<$ 0.05, Perm test, Siegel \& Castellan 1988).

\section{Mass of food ingested by trip}

Table 2 shows estimations of food intake for satellitetracked birds while on southward trips. From 12 to $60.9 \mathrm{~kg}$ of food was captured during the trips at sea, which gives an average consumption by each penguin of $2.5 \pm 0.8 \mathrm{~kg} \mathrm{~d}^{-1}(\mathrm{n}=6$. Table 2$)$. The total mass of the food ingested during the trip significantly increased with the length of the journey (Spearman' rank correlation coefficient, $\left.r_{S}=0.90, p<0.05\right)$. For all birds studied, the major part of food intake occurred during the first phase of the trip, with an average yield of $80.7 \pm 8.40 \%$ by mass (Table 2). During the second phase, the last recorded periods of feeding took place between $60 \mathrm{~h}(7.9 \mathrm{~kg})$ and $18 \mathrm{~h}(1.3 \mathrm{~kg})$ before returning to the colony, i.e. respectively at 320 and $70 \mathrm{~km}$ away from the colony.
Food ingestion in relation to latitude

The major intake of food occurred in 2 latitudinal bands: 1 sector between $47^{\circ}$ and $48^{\circ} \mathrm{S}$ with 33 to $56 \%$ of food mass ingested, and another sector between $48.50^{\circ}$ and $50^{\circ} \mathrm{S}$ with 30 to $65 \%$ of food mass ingested (Fig. 3).

During the summer, king penguins with an egg or brooding chick may feed during the entire first phase of trips directed toward the south (Fig. 4). First food intake occurred at $35 \pm 24 \mathrm{~km}$ from the colony with an average meal size of $0.7 \pm 0.4 \mathrm{~kg}(\mathrm{n}=6)$. The earliest intake of food was observed $4 \mathrm{~km}$ from the colony and corresponded to a estimated mass of $1.4 \mathrm{~kg}$ ingested in $4 \mathrm{~h}$ (bird no. 240-1). Some incubating birds had meals of $0.9 \mathrm{~kg}$ at $40 \mathrm{~km}$ from the colony less than $24 \mathrm{~h}$ after having left.

\section{Food ingestion and time spent by foraging sector}

There was a positive relationship between the time spent in an increment of latitude $\left(0.5^{\circ}\right)$ and the mass of food ingested there for all the birds studied except one (Table 2). Birds achieved their highest CPUE index in the sectors between $47^{\circ}$ and $48^{\circ} \mathrm{S}$ and between $50^{\circ}$ and $50.50^{\circ} \mathrm{S}$ (Fig 3). Bird no. 315-1 which had the southernmost foraging range $\left(50.52^{\circ} \mathrm{S}\right)$ also showed the highest CPUE index, observed at the limit of its range. All the CPUE index values corresponding to food intake close to the colony (i.e. $46^{\circ}$ to $46.5^{\circ} \mathrm{S}$ ) were comparatively low (Fig 3).

Food intakes were more frequent during slowing down periods than for the rest of the trip $\left(\chi_{1}^{2}=111.76\right.$. 921 feeding periods, $n=5$ trips). Reported in biomass, more than half of the prey was ingested during the slowing down periods (mean $54.8 \pm 9.9 \%$, Table 2 ), which represented $40.6 \pm 12.9 \%$ of the trip duration (Table 1).

Table 2. Mass ingested during time at sea for 6 king penguins on southward trips in February 1994 according to the stage of the trip and the area of use. $\cdots p<0.005, \cdots p<0.05$, ns: $p>0.05$

\begin{tabular}{|c|c|c|c|c|c|c|c|c|c|c|c|c|c|c|}
\hline \multirow{3}{*}{$\begin{array}{l}\text { Bird } \\
\text { no. }\end{array}$} & \multicolumn{2}{|c|}{$\longrightarrow \operatorname{Trtp} \_$} & \multicolumn{4}{|c|}{ Phase } & \multirow{2}{*}{\multicolumn{2}{|c|}{$\begin{array}{l}\text { Slowing down } \\
\text { areas }\end{array}$}} & \multirow{2}{*}{\multicolumn{2}{|c|}{$\begin{array}{c}\text { Traveling } \\
\text { areas }\end{array}$}} & \multirow{2}{*}{\multicolumn{4}{|c|}{$\begin{array}{l}\text { reas - } \\
\text { Mass ingested per time spent } \\
\text { in each } 0.5^{\circ} \text { latitude increment }\end{array}$}} \\
\hline & \multirow{2}{*}{$\begin{array}{l}\text { Duration } \\
\text { of trip } \\
\text { (d) }\end{array}$} & \multirow{2}{*}{$\begin{array}{l}\text { Mass/24 h } \\
\text { (kg) }\end{array}$} & \multicolumn{2}{|c|}{ Phase 1} & \multicolumn{2}{|c|}{ Phase 2} & & & & & & & & \\
\hline & & & $(\mathrm{kg})$ & $1 \%$ & $(\mathrm{~kg})$ & $\%$ & $(\mathrm{~kg})$ & $\%$ & $(\mathrm{~kg})$ & $\%$ & $\mathrm{r}$ & $t$ & $\mathrm{n}$ & $\mathrm{p}$ \\
\hline $240-1$ & 10 & 2.4 & 17.0 & 72.3 & 6.3 & 27.0 & 8.8 & 37.7 & 14.5 & 62.2 & 0.36 & 3.6 & 79 & $\cdots$ \\
\hline $315-1$ & 25 & 2.5 & 53.4 & 87.7 & 7.5 & 12.3 & 36.6 & 60.1 & 24.3 & 39.9 & 0.24 & 2.1 & 73 & $\cdots$ \\
\hline $240-2$ & 11 & 3.0 & 25.0 & 76.0 & 7.9 & 24.0 & 20.6 & 62.6 & 12.3 & 37.4 & 0.28 & 2.8 & 87 & $\cdots$ \\
\hline $316-2$ & 9 & 4.0 & 27.8 & 76.4 & 8.6 & 23.6 & 20.2 & 55.5 & 16.2 & 44.5 & 0.40 & 36 & 71 & $\cdots$ \\
\hline $239-1^{d}$ & 15 & 1.1 & - & - & - & - & 7.2 & 58.3 & 5.2 & 41.6 & 0.15 & 0.97 & 43 & ns \\
\hline $317.2^{b}$ & 7 & 2.1 & 11.1 & 92.0 & 0.9 & 8.0 & - & - & - & - & - & - & - & - \\
\hline
\end{tabular}


Fig. 3. Mass of food ingested (vertical bars) in relation to latitude and amount of catch per time spent in each $0.5^{\circ}$ latitude section (CPUE index, solid line) for 4 birds monitored successfully during their southward trip (240-1, 240-2, 316-2: brooding; 315-1: Incubating)

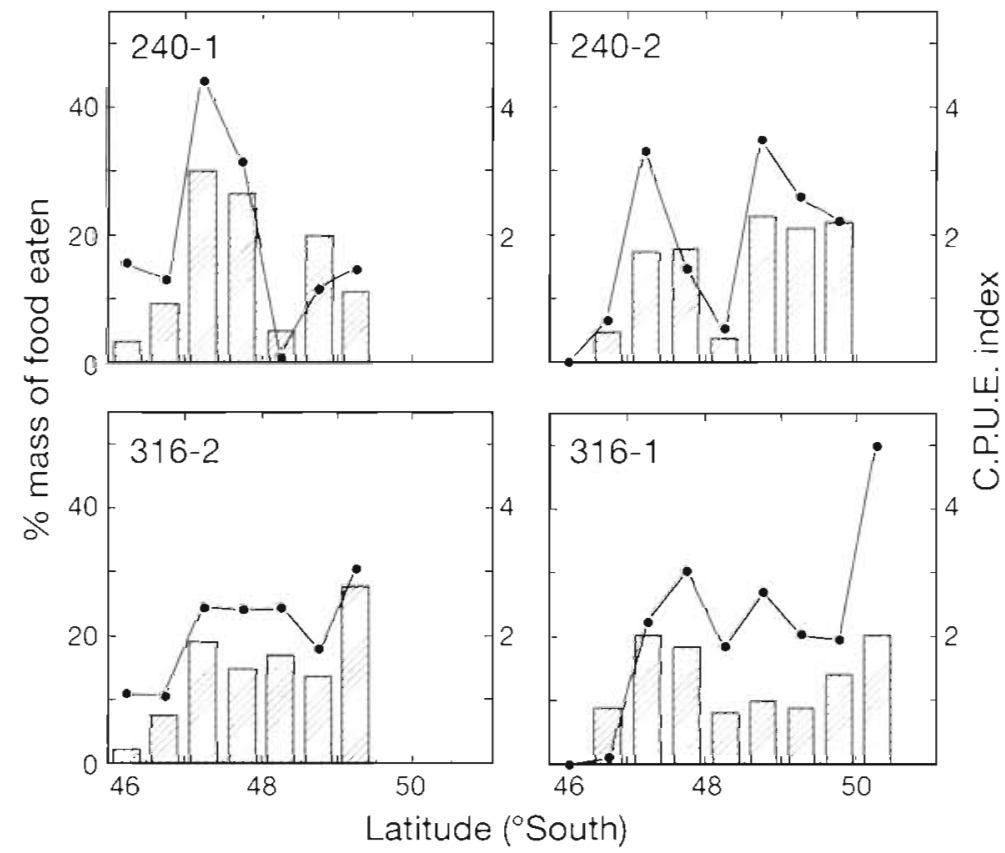

(a)

Fig. 4. Movements at sea and feeding activity of southward foraging king penguins during (a) brooding and (b) incubating as determined by satellite tracking and stomach temperature recorder. Each plotted location of feeds corresponds to the beginning of the feeding period. Each unit of the vertical contours corresponds to $30 \mathrm{~min}$

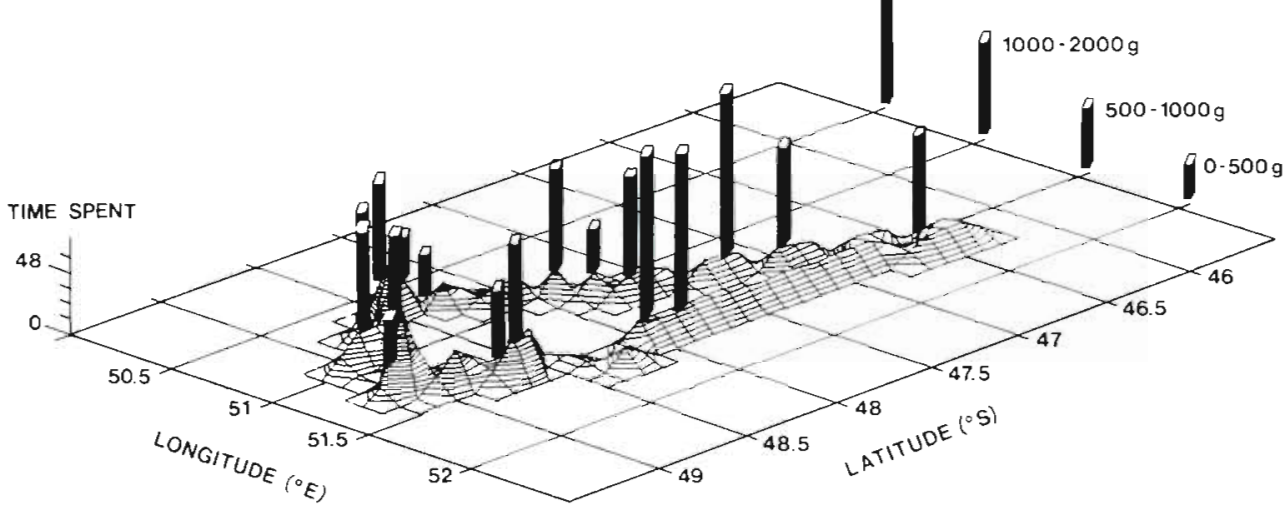

(b)

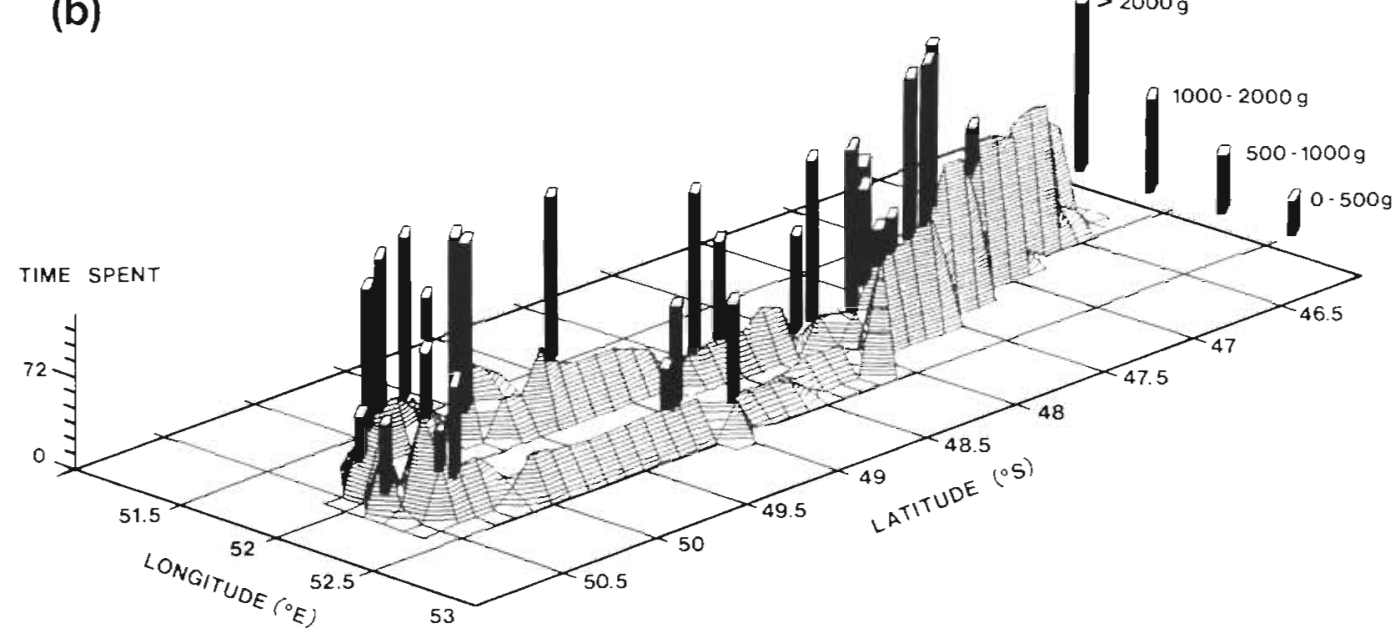




\section{Diet}

\section{General composition}

Myctophid fishes represented the main part of the diet during the study period $198 \%$ by numbers and $90 \%$ by reconstituted mass). The main prey species or group of species were Electrona carlsbergi. Krefftichtys anderssoni, and Protomyctophum spp. (mainly P. tenisoni, Table 3). Electrona carlsbergi dominated the diet in biomass in February 1993 (70.1\%), whereas in February 1994 it represented only $15.3 \%$. Protomyctophum spp. were twice as common in February 1994 as in February 1993 (Table 3).

\section{Individual sampling}

Table 4 gives the number of the main prey found in the stomach contents of 6 birds fitted simultaneously with satellite transmitters and feeding recorders. All of these birds performed southward trips. Individual analysis of samples showed the predominance of Krefftichtys anderssoni and. Protomyctophum tenisoni by numbers and by reconstituted biomass (Table 4). The 3 samplings where Krefftichtys anderssoni was most abundant $(84.1,91.1$ and $92.4 \%)$ were recovered from birds having large foraging ranges (respectively 397,456 , and $405 \mathrm{~km}$, i.e. $49.91^{\circ} \mathrm{S}, 50.50^{\circ} \mathrm{S}$, and $50.10^{\circ} \mathrm{S}$ ). Two of these birds (king penguins 240-2 and 315-1) stopped to feed when traveling back at respectively 265 and $77 \mathrm{~km}$ away from Possession Island. King penguin 316-2, which had a diet composed mostly of P. tenisoni (60.1\% by number), stopped eating at $49^{\circ} \mathrm{S}$, or $322 \mathrm{~km}$ from Possession Island.

\section{DISCUSSION}

Our study has led to 5 major findings about king penguin foraging ecology in relation to hydrographic features of the Polar Frontal Zone: (1) the birds do not forage randomly but concentrate their foraging effort in specific areas; (2) they forage intensively at the northern limit of the Polar Front, at the southern limit of the Sub-Antarctic Front and in the sectors between $47^{\circ}$ and $48^{\circ} \mathrm{S}$; (3) their foraging range is related to inter-year variations of oceanic front positions; (4) when traveling south, they feed on prey patches along their outgoing trip; and (5) the highest food intakes were recorded at the northern limit of the Polar Front and in the sections between $47^{\circ}$ and $48^{\circ} \mathrm{S}$. We will discuss these findings in detail below after examining the effect of the transmitters on the birds foraging efficiency.

Table 3. Frequency of occurrence (F.O.), number of items and wet mass of the main prey in the stomach contents of king penguins in February 1993 and February 1994

\begin{tabular}{|c|c|c|c|c|c|c|c|c|c|c|}
\hline & \multicolumn{5}{|c|}{ February $1993(\mathrm{n}=10)$} & \multicolumn{5}{|c|}{ February $1994(\mathrm{n}=7)$} \\
\hline & \multirow[t]{2}{*}{ F.O. } & \multicolumn{2}{|c|}{ Numbers ${ }^{\circ}$} & \multicolumn{2}{|c|}{ Mass } & \multirow[t]{2}{*}{ F.O. } & \multicolumn{2}{|c|}{ Numbers ${ }^{d}$} & \multicolumn{2}{|c|}{ Mass } \\
\hline & & Items & $\%$ & $(g)^{\text {d }}$ & $\%$ & & Items & $\%$ & $(g)^{a}$ & $\%$ \\
\hline Krefftichtys anderssoni & 0.8 & 1795 & 60.5 & 1324 & 15.6 & 0.8 & 1709 & 65.8 & 1404 & 36.6 \\
\hline Protomyctophum tenisoni & 0.3 & 507 & 17.1 & 1212 & 14.3 & 0.6 & 380 & 14.6 & 851 & 22.2 \\
\hline Protomyctophum sp." & - & - & - & - & - & 1.0 & 443 & 17.1 & $992^{c}$ & 25.9 \\
\hline Electrona carlsbergi & 1 & 663 & 22.3 & 5947 & 70.1 & 0.6 & 64 & 2.5 & 586 & 15.3 \\
\hline
\end{tabular}

Table 4. Importance by numbers and by mass of the main prey items in the stomach contents of 6 satellute-tracked southwardbound king penguins fitted with feeding activity recorders in February 1994

\begin{tabular}{|c|c|c|c|c|c|c|c|c|c|c|c|c|c|c|c|c|}
\hline \multirow{3}{*}{$\begin{array}{l}\text { Bird } \\
\text { no. }\end{array}$} & \multicolumn{4}{|c|}{ Krefftichtys anderssoni } & \multicolumn{4}{|c|}{ Protomyctophum spp. ${ }^{\circ}$} & \multicolumn{4}{|c|}{ Electrona carlsbergi } & \multicolumn{4}{|c|}{ Gymnoscopelus nicholst } \\
\hline & \multicolumn{2}{|c|}{ Number } & \multicolumn{2}{|c|}{ Mass } & \multicolumn{2}{|c|}{ Number } & \multicolumn{2}{|c|}{ Mass } & \multicolumn{2}{|c|}{ Number } & \multicolumn{2}{|c|}{ Mass } & \multicolumn{2}{|c|}{ Number } & \multicolumn{2}{|c|}{ Mass } \\
\hline & (n) & $\%$ & $(g)$ & $\%$ & $(n)$ & $\%$ & $(g)$ & $\%$ & (n) & $\%$ & (g) & $\%$ & $(n)$ & $\%$ & (g) & $\%$ \\
\hline $239-1$ & 402 & 92.4 & 322 & 82.4 & 33 & 7.6 & 69 & 17.6 & - & - & - & - & - & - & - & - \\
\hline $240-1$ & 93 & 32.9 & 74 & 11.0 & 160 & 56.5 & 336 & 49.8 & 30 & 10.6 & 264 & 39.2 & - & - & - & - \\
\hline $316-2$ & 126 & 39.9 & 100 & 20.9 & 190 & 60.1 & 378 & 79.1 & - & - & - & - & - & - . & - & - \\
\hline $315-1$ & 350 & 91.1 & 280 & 79.8 & 34 & 8.9 & 71 & 20.2 & - & - & - & - & - & - & - & - \\
\hline $240-2$ & 132 & 84.1 & 105 & 44.3 & 13 & 8.3 & 27 & 11.4 & 12 & 7.6 & 105 & 44.3 & - & - & - & - \\
\hline $317-2$ & - & - & - & - & 158 & 83.2 & 331 & 47.8 & - & - & & - & 32 & 16.8 & 361 & 52 \\
\hline
\end{tabular}




\section{Effect of satellite transmitters on foraging behavior}

Although essential in the study of the behavior of penguins at sea, it is now well established that recording devices may affect their foraging efficiency (Wilson et al. 1986, Bannasch et al. 1994). In our study, the king penguins with both satellite transmitters and feeding activity recorders had longer stays at sea and had a modified timing of feeding. In king penguins, myctophid capture rates are usually much greater during the day than at night (respectively 83 and $17 \%$ of the feeding events; Pütz \& Bost 1994). During the day, myctophids are distributed in dense patches at a variety of depths below $100 \mathrm{~m}$. During the night, they rise to the 0-30 m upper layer (Zasel'sliy et al. 1985, G. Duhamel pers. comm.). While myctophids appear to be more accessible to king penguins during the night, it has been suggested that penguins are less successful at foraging then because the low light levels may limit the depth of dives (Wilson et al. 1993). During our study, birds fitted with transmitters increased their capture rate during the night. This difference may have resulted from changes in diving effort with a decrease of energetically costly deep dives during the day (Kooyman et al. 1992)

However, even if the satellite transmitters had an noticeable influence on the energetic cost of foraging, it seems that the foraging behavior was not radically modified. Indeed, the maximum foraging ranges of the encumbered birds were similar to those observed for birds equipped with miniaturized loggers to estimate the geographic location at sea on a daily basis from light level data (Pütz 1994).

\section{Foraging areas and hydrographic features}

Our study shows that king penguins concentrate their foraging effort in specific areas of the Polar Frontal Zone, located between the Sub-Antarctic Front and the Polar Front. The most highly frequented areas corresponded to the eastern and south-eastern limits of the foraging trips. These sectors also corresponded to the position of the Polar Front and Sub-Antarctic Polar Front on the same time scale as determined from the sea-surface temperature distribution (Guinet et al. 1997). Thus, the $4^{\circ} \mathrm{C}$ surface isotherm defining the Polar Front (Deacon 1982) was $2^{\circ}$ latitude farther south in $1993\left(52.50^{\circ} \mathrm{S}\right)$ in comparison with 1992, at the limit of the penguins' foraging range. During the same year, the sectors most highly frequented by the penguins were located between $50.50^{\circ}$ and $51.50^{\circ} \mathrm{S}$, i.e. $110 \mathrm{~km}$ farther south, at the northern limit of the Polar Front. In February 1994, the Polar Front also reached its southernmost position recorded during summers 1992-94, but the birds concentrated most of their time at sea $(40 \%)$ at the limit of its nor thern position. This could be partly related to the breeding status of tracked birds, most of those brooding small chicks requiring short trips while most of the penguins studied at sea in 1992 and 1993 were incubating and had longer foraging trips

For the trips oriented toward the Sub-Antarctic Front, the inter-year comparison of the time spent by sector showed the same trend, since the birds concentrated their foraging time in the zone where the Sub-Antarctic Front was the most apparent. Thus, the areas $45^{\circ}-45.50^{\circ} \mathrm{S} / 53.50^{\circ}-54^{\circ} \mathrm{E}$ and $45^{\circ}-45.80^{\circ} \mathrm{S} /$ $54.50^{\circ}-55.50^{\circ} \mathrm{E}$, which were highly frequented in 1993 and 1994 , also corresponded to the isotherms $8-9^{\circ} \mathrm{C}$ (1993) and $9-10^{\circ} \mathrm{C}$ (1994) (Guinet et al. 1997)

Although the sample size was limited, our results do not indicate any difference in foraging zone location (eastward or southward) among king penguin colonies on Possession Island. In contrast, some separation of feeding zones seems to occur for wandering albatross colonies breeding at Possession Island (Weimerskirch et al. 1993). During the short trips of the chick-rearing period, wandering albatrosses forage on some restricted areas at the edge of the shelf. Consequently, separation of feeding zones is consistent with the hinterland model (Cairns 1989) which predicts that seabirds from neighboring colonies forage in distinct zones. For king penguins breeding on Possession Island, foraging occurs over far-off frontal zones and the total foraging surface area available is very large whatever the colony location, thus preventing separation of feeding zones.

\section{Relations among food intake, diet and availability of oceanic resources}

For trips oriented toward the Polar Front, the simultaneous monitoring of food intake and movement of king penguins in 1994 revealed 2 particularly favourable sectors for feeding activity in terms of food intake and catch per unit effort: the section between $47^{\circ}$ and $48^{\circ} \mathrm{S}$ and the section between $48.50^{\circ}$ and $50.50^{\circ} \mathrm{S}$, where sea-surface temperature were between 6.5 and $7^{\circ} \mathrm{C}$ and between 5.5 and $6^{\circ} \mathrm{C}$, respectively (Guinet et al. 1997). For these 2 sectors, bathymetric data indicates depths ranging between 2000 and $4000 \mathrm{~m}$, without any noticeable discontinuity (Koubbi 1993). High foraging success for king penguins in the sector $47^{\circ}-48^{\circ} \mathrm{S}$ was observed for brooding as well as incubating birds. More data on foraging success are needed to confirm the importance of this sector in terms of food intake. The limits of the second sector coincided with the northern limit of the Polar 
Front, i.e. the coldest part of the foraging area. Analysis of stomach contents showed the predominance of myctophids in the diet of the studied birds. This result is very similar to those already known for king penguins in summer in the localities north of the Polar Front (Adams \& Klages 1987, Hindell 1988, Cherel \& Ridoux 1992) Although myctophids dominate the Polar Frontal Zone, the maximum biomass is usually higher within the Polar Front (and the Sub-Antarctic Front) than in the interfrontal zone (Sabourenkov 1991. Pakhomov et al. 1994). Accordingly, the maximal food intake per foraging time was obtained by the bird that approached closest to the limit of the Polar Front. Although other data are still required, this result shows the interest of the northern limit of the Polar Front to oceanic birds like the king penguin for their feeding ecology, in terms of foraging success.

Diet analysis of satellite-tracked birds allows examination of whether the stomach contents of returning penguins were representative of the whole foraging trip. When at sea, penguins appear to eat firstly for themselves, quickly digesting the prey caught to cover their own energetic demands, and then afterwards catch prey to bring back to the chick (Wilson \& Wilson 1995). It seems unlikely that the stomach contents recovered in this study reflected only the myctophids caught in the immediate vicinity of the colony. Thus, data recovered from the birds fitted with stomach temperature sensors in combination with satellite transmitters demonstrated that the penguins stopped to feed between 77 and $322 \mathrm{~km}$ away from the colony. In addition, prey determination and quantification was performed from otoliths found enclosed in myctophids skulls and otoliths found free in the content but unaltered, i.e. coming from prey caught during the same foraging trip. Thus, although no bias can be excluded, we make the assumption that the stomach contents recovered reflected mainly the prey eaten during the last feeding period and those caught before the birds began to travel back to the colony, corresponding to prey eaten in the farthest foraging area reached.

Three myctophid species, Electrona carlsbergi, Kreffichtys anderssoni, and Protomyctophum tenisoni, dominated the diet. They are among the 4 most abundant myctophid species in the Southern Ocean (Lubimova et al. 1987). The importance by number of $K$ anderssoni in the diet compared to E. carlsbergi and Protomyctophum spp. in February 1993 and 1994 confirms the dominance of this species in the food of king penguins at that time of the year (Cherel \& Ridoux 1992).

Comparison of movements at sea and diet composition of individually tracked penguins provided additional information on the distribution of mesopelagic fish. Thus, the analysis of the diet of satellite-tracked birds suggests that Kreffichtys anderssoni was abundant for the penguins between $49^{\circ}$ and $50.50^{\circ} \mathrm{S}$, i.e. at the northern limit of the Polar Front. This confirms data obtained through oceanic campaigns in this area (Koubbi 1993). The average temperature at $200 \mathrm{~m}$ extrapolated from sea-surface temperature data in this latitudinal band (i.e. $3^{\circ} \mathrm{C}$, Guinet et al. 1997) accords with the optimal temperature for $K$. anderssoni (Hulley 1981). An apparently reduced availability of $K$. anderssoni at the peri insular zone of Crozet is also in accordance with the observations of Perissinoto \& McQuaid (1992) at Prince Edward Island $\left(47^{\circ} \mathrm{S}, 38^{\circ} \mathrm{E}\right)$. This may indicate that $K$. anderssoni is mainly present in open ocean waters, well-off the shelf-break which does not appear favourable to support large permanent densities of this species.

As an another major prey species, Electrona carlbergi, also showed the largest change in diet contribution from 1993 to 1994. In February 1994, the small abundance of $E$. carlsbergi in the diet could have been related to the reduced distribution of king penguins in the southern sectors of the Polar Frontal Zone at this time of the year compared to February 1993. Indeed, these sectors are highly favorable for the feeding activity of $E$. carlsbergi which form very dense shoals here (Koslov et al. 1991).

Protomyctophum tenisoni was the third dominant species in the diet of the tracked birds. Largely distributed between the Sub-Tropical Front and the Polar Front (Gon \& Heemstra 1990), P. tenisoni has a poorly known distribution in the southwestern Indian Ocean. Our results suggest that the availability of $P$. tenisoni could be favourable for king penguins between $47.5^{\circ}$ and $50.50^{\circ} \mathrm{S}$, at the northern limit of the Polar Front.

\section{Foraging strategy and availability of oceanic resources}

For southward trips, comparison of food intake for the different oceanic areas suggests a higher foraging success for those birds concentrating their foraging effort at the northern limit of the Polar Front. Although no feeding data were obtained for eastward trips, intense foraging within the Sub-Antarctic Front is likely to be profitable in terms of foraging yield because of the high biomass of myctophids there (Pakhomov et al. 1994).

During foraging trips oriented towards the Polar Front, an analysis based on mean traveling speed shows 2 distinct phases. The first occurred from departure to the last location, corresponding to a speed inferior to the average of the trip. The second occurred from this last location back to the colony. The first phase corresponded to the combination of the direct 
path and the foraging period indicated by Jouventin et al. (1994). By using satellite transmitters and stomach temperature recorders simultaneously on the same individuals, our study was able to provide the first evidence that king penguins feed intensively during the entire first phase towards the Polar Front. Feeding activity occurred in several patches, rather than in a single large patch at the limits of the Polar Front. This pattern of feeding was used both by brooding birds, which have a more restricted foraging time, as well as by incubating birds which spend more time at sea and are able to go farther.

By monitoring the feeding activity of individually tracked birds, our study provides new insight for the interpretation of the relationship between distribution and abundance of diving birds (e.g. penguins and alcids) and of prey abundance. Inside large selected foraging areas, king penguins feed during the entire first phase of their trip but seem to concentrate their foraging effort over medium scales, notably at the limit of the frontal zone. The 'slowing down' periods that occurred mainly during these outgoing parts were also found to be associated with higher food intake compared to the rest of the trip. Thus, once a patch is detected, king penguins seem to slow down their horizontal displacement, probably trying to concentrate their foraging effort within a local area and catch prey by intensive diving activity rather than looking for new patches. This accords with the observations made about diving and displacements of other foraging penguins (e.g Spheniscus spp.; Wilson \& Wilson 1995). Afterwards, king penguins return back directly to their colony with reduced foraging activity. This might partly explain the weak correlation observed between abundance at sea of Antarctic penguins (e.g. macaronis and chinstrap) and patchy distributed prey (e.g. krill) especially on a small scale (Heineman 1989, Hunt et al. 1992)

When traveling to the Polar Front, king penguins may feed extensively during the first days at sea for trips ending up in areas where the availability of myctophids might be optimal for the penguins. This raises the question of why the birds go farther south when they encounter prey close to their colony. This may be explained by a marked change in myctophid density over and downstream of the shelf during daytime as at Marion Island (Perissinotto \& McQuaid 1992), their high mobility in space (Zasel'sliy et al. 1985), and a less abundant myctophid biomass as reflected by low CPUE of instrumented birds. The long distances which king penguins commute to frontal zones does not necessarily involve an additional energy cost. Even in heavy wing-loaded seabirds like auklets, long-distance commuting between the colony and feeding areas does not significantly change total energy expenditure (Obst et al 1995). Optimal foraging models predict that the decision to take prey supplying minor energy intake while traveling to an optimal patch is beneficial if it enables increasing the rate of energy gain per unit foraging time (Orians \& Pearson 1979, Lessels \& Stephens 1983). In accordance with these predictions, king penguins probably prospect actively along all the first phase of the trip in localized patches of more uncertain detection but which are energetically profitable. Thus, the diving activity is intense for the first few kilometers spent at sea, the birds alternating traveling dives and searching dives with deep dives (Charrassin, Bost, Pütz, Lage, Zorn, Le Maro unpubl.). The prolonged fast spent at the colony during incubation or brooding duties is probably a factor which influences king penguins to maximize their energetic gain as they leave the colony. This may explain why some appreciable food ingestion can be observed during the first day at sea for trips which end up in areas where the availability of myctophids appear to be optimal for the penguins. During the second phase of the trip, the increase in mean speed could be connected to the low feeding activity observed. This shows that king penguins increase their horizontal displacements favoring traveling dives as has been demonstrated for other penguins (Wilson \& Wilson 1990, Weavers 1992). This second phase starts probably when the energy reserves and food intake for the chick is sufficient and when the time already spent at sea, added to the anticipated time required to reach the colony, approach a threshold (Weimerskirch et al. 1994). Further work using satellite tracking in conjunction with feeding activity recorders in birds of known breeding status is still needed to confirm these results.

\section{CONCLUSION}

The foraging strategy of the king penguin during summer favors displacements toward frontal zones and especially the Polar Front which appears to be the most profitable in terms of energy yield. In accordance with predictions of optimal foraging models, king penguins feed intensively during the entire phase towards the Polar Front, increasing the rate of energy gain per unit foraging time. Future studies should strive to determine why king penguins do or do not navigate alternatively towards the Polar Front or the Sub-Antarctic Front and how they locate optimal feeding areas from year to year. The interpretation of the foraging ecology of the king penguin and of other long-distance foragers will greatly benefit from additional studies regarding feeding activity and energy expenditure in relation to prey availability. 
Acknowledgements. We are especially indebted to the Institut Français pour la Recherche et la Technologie Polaires and Terres Australes et Antarctiques Françaises for financial and logistical support, and to the Centre National de la Recherche Scientifique (CNRS), PIC162 and EEC (grant SCI-0273) for financial support. We are very grateful to $\mathrm{V}$, and J. Klinger, $\mathrm{C}$. Sidot and P. Doncaster for development of computers programs, R. Seyller for collecting and transmitting the satellite data and J. P. Gendner for his help in the setting up and use of transmitters. We thank C. Boiteau, F. Cuenot-Chaillet, S. Eudes, F. Lagarde, R. Wilson, E. Valentini and the members of Missions 29, 30 and 31 at Crozet for their generous assistance. A. Pape improved the English and 3 anonymous referees provided many constructive suggestions and comments that were greatly appreciated by the authors.

\section{LITERATURE CITED}

Adams NJ, Klages NT (1987) Seasonal variation in the diet of the King penguin Aptenodytes patagonicus at SubAntarctic Marion Island. J Zool (Lond) 212:303-324

Ancel A, Kooyman GL, Ponganis JP, Gendner JP, Lignon J, Mestre $X$, Huin N, Thorson PH, Robisson P, Le Maho Y (1992) Foraging behaviour of Emperor penguins as a resource detector in winter and summer. Nature 360:336-339

Bannasch R, Wilson RP, Culik B (1994) Hydrodynamic aspects of design and attachment of a back mounted device in penguins. J Exp Biol 194:83-96

Bekker VE, Evseenko SA (1987) Distribution of mesopelagic fishes and biogeographic borders in the Suuthern Pacific Ocean in January-February 1985. J Ichthyol 27(1):9-20

Cairns DK (1989) The regulation of seabird colony size: a hinterland model. Am Nut 134:141-146

Chappell MA, Shoemaker VH, Janes DJ, Bucher TL, Maloney SK (1993) Diving behaviour during foraging in breeding Adelie penguins. Ecology 74(4):1204-1215

Cherel Y, Ridoux V (1992) Prey species and nutritive value of food fed during summer to King penguin Aptenodytes patagonica chicks at Possessıon Island, Crozet Archipelago. Ibis 134:118-187

Croxall JP, Briggs DR, Kato A, Naito Y, Watanuki Y, Williams $\mathrm{T}$. (1993) Diving pattern and performance of the Macaroni penguin Eudyptes chrysolophus. J Zool (Lond) 230:31-47

Croxall JP, Prince PA (1987) Seabirds as predators on marine resources, especially krill, at South Georgia. In: Croxall JP (ed) Seabirds, feeding ecology and role in marine ecosystems. Cambridge University Press, Cambridge, p 347-369

Davis LS, Miller GD (1992) Satellite tracking of Adelie penguins. Polar Biol 12:503-506

Deacon GER (1982) Kerguelen, Antarctic and Subantarctic. Deep Sea Res 30:77-81

El-Sayed SZ (1988) Seasonal and interannual variabilities in Antarctic phytoplankton with reference to krill distribution. In: Sahrage D (ed) Antarctic Ocean and resources variability. Springer-Verlag, Berlin, p 101-119

Gon O, Heemstra PC (1990) Fishes of the Southern Ocean. JLB Smith Institute of Ichthyology, Grahamstown

Guinet C, Cherel Y, Ridoux V, Jouventin P (1996) Consumption of marine resources by seabirds and seals in Crozet and Kerguelen waters: changes in relation to consumer biomass trends over 1962-85. Antarct Sc1 8:23-30

Guinet C, Koudil M, Bost CA, Durbec JP, Georges JY, Mouchot MC, Jouventin P (1997) Foraging behaviour of satellite-tracked king pengums in relation to sea-surface temperatures obtained by satellite telemetry at Crozet Archipelago: a study during three austral summers. Mar
Ecol Prog Ser 150:11-20

Heinemann D. Hunt G, Everson I (1989) Relatıonships between the distributions of marine avian predators and their prey, Euphausia superba, in Bransfield Strait and southern Drake Passage. Antarctica. Mar Ecol Prog Ser 58:3-16

Hindell MA (1988) The diet of the King penguin Aptenodytes patagonicus at Macquarie Island. Ibis 130:193-203

Hulley PA (1981) Results of the research cruise of FRV 'Walter Herwig' to South America LVIII. Family Myctophidae (Osteichthyes Myctophiformes). Arch Fisch Wiss 31(1): $1-300$

Hunt GL Jr, Heinemann D, Everson I (1992) Distributions and predator-prey interactions of Macaroni penguins, Antarctic fur seal, and Antarctic krill near Bird Island, South Georgia. Mar Ecol Prog Ser 86:15-30

Jouventin P, Capdeville D, Cuenot-Chaillet F, Boiteau C (1994) Exploitation of pelagic resources by a non-flying seabird: satellite tracking of the king penguin throughout the breeding cycle. Mar Ecol Prog Ser 106:11-19

Kooyman GL, Cherel Y, Le Maho Y, Croxall JP, Thorson PH, Ridoux $V$, Kooyman CA (1992) Diving behaviour and energetics during foraging cycle in King penguins. Ecol Monogr 62:143-163

Koslov AN, Shust KV, Zemsky AV (1993) Seasonal and interannual variability in the distribution of Electrona carlsbergi in the southern Polar Front area. Selected Scientific Papers Scientific Committee Conservation Antarctic Living Resources (CCAMLR) 1990, Hobart p 337-367

Koubbi P (1993) Influence of the frontal zones on ichtyoplankton and mesopelgic fish assemblages in the Crozet Basin (Indian sector of the Southern Ocean). Polar Biol 13 $557-564$

Lessels CM, Stephens DW (1983) Central place foraging: single prey loaders again. Anim Behav 31:238-243

Lubimova TG, Shust KV, Pokov VV (1987) Some features on the ecology of mesopelagic fish of family myctophidae in the Southern Ocean. Biological resources of the Arctic and Antarctic. Nauka, Moscow, p 320-337

Lutjerharms JRE (1985) Location of frontal systems between Africa and Antarctica: some preliminary results. Deep Sea Res 32:1459-1509

Obst BS, Russell RW, Hunt JR, Eppley ZA, Harrison NM (1995) Foraging radii and energetics of Least auklets (Aethia pusilla) breeding on three Bering islands. Physiol Zool 68(4):647-672

Orians $\mathrm{CH}$, Pearson NE (1979) On the theory of Central Place Foraging. In: Horn JD, Mitchell R, Stair GR (eds) Analysis of ecological systems. Ohio Sate University Press, Columbus, p 154-177

Pakhomov EA, Perissinotto R, McQuald CD (1994) Comparative structure of the macrozooplankton/micronekton communties of the Subtropical and Antarctic Polar Fronts. Mar Ecol Prog Ser 111:155-169

Park YH, Gamberoni L, Charriaud E (1991) Frontal structure, and transport of the Antarctic Circumpolar Current in the South Indian Ocean sector, 40-80 E. Mar Chem 35:45-62

Perissinotto R, MC Quaid CD (1992) Land based predator impact on vertically migrating zooplankton and micronekton adverted to a southern ocean archipelago. Mar Ecol Prog Ser 80:15-27

Pütz K (1994) Untersuchungen zur Ernahrungsökologie von Kaiserpinguinen Aptenodytes forsteri and Königspinguinen Aptenodytes patagonicus. Berichte zur Polarforschung 136. Alfred Wegener Institut für Polar- und Meeresforschung, Bremerhaven

Pütz K, Bost CA 11994 \} Feedıng behavıour of free-ranging 
Kung penguins Aptenodytes patagonicus. Ecology 75 : 489-497

Sabourenkov EN (1991) Mesopelagic fish of the southern ocean-summary results of recent Soviet studies. Selected Scientific Papers Scientific Committee Conservation Antarctic Living Resources (CCAMLR) 1990, Hobart, p $433-457$

Siegel S, Cãstellan NJ Jr (1988) Non-parametric statistics for the behavioral sciences, 2nd edn. McGraw-Hill, New-York

Sokal RR, Rohlf FJ (1981) Biometry, 2nd edn. Freeman, London

Weavers BW (1992) Seasonal foraging ranges and travels at sea of little blue penguins Eudypiula minor, determined by radıotracking. Emu 91:302-307

Weimerskurch H, Doncaster P, Cuenot-Chaillet F (1994) Pelagic seabirds and the marine environment: foraging patterns of Wandering albatrosses in relation to prey availability and distribution. Proc R Soc Lond Ser B Biol Sci 255:91-97

Weimerskirch H, Salamolard M, Sarrazin F, Jouventin P (1993) Foraging strategy of Wandering albatrosses through the breeding season: a study using satellite telemetry. Auk 110(2):325-342

Wermerskirch H, Stahl JC, Jouventin P (1992) The breeding biology and population dynamics of king penguins Aptenodytes patagonica on the Crozet Island. Ibis 134: $107-117$

Wilson RP (1984) An improved stomach pump for penguins and other seabirds. J Field Ornithol 55:9-12

Wilson RP, Cooper J, Plötz J (1992) Can we determine when

This article was submitted to the editor marine endotherms feed? A case study with seabirds J Exp Biol 167:267-275

Wilson RP, Culik BM, Bannasch R, Lage J (1994) Monitoring Antarctic environmental variables using penguins. Mar Ecol Prog Ser 106:199-202

Wilson RP, Grant WS, Duffy DC (1986) Recording devices on free-ranging marine animals: does measurement affect performance? Ecology 67:1091-1093

Wilson RP, Pütz K, Bost CA, Culik BM, Bannasch R, Reıns T, Adelung $D$ (1993) Diel dive depth in penguins in relation to diel vertical migration of prey: whose dinner by candlel.ght? Mar Ecol Prog Ser 94:101-104

Wilson RP, Pütz K, Gremillet D, Culik B, Kierspel M, Regel J, Bost CA, Lage J (1995) Reliability of stomach temperature changes in determining feeding characteristics of seabirds. J Exp Biol 198:1115-1135

Wilson RP, Wilson MP (1990) Foraging ecology of breeding Spheniscus penguins. In: Davids LS, Darby JT (eds) Penguin biology. Academic Press, San Diego, p 181-206

Wilson RP. Wilson MP (1995) The foraging behaviour of the African penguin Spheniscus demersus. In: Dann P, Norman l, Reilly $P$ (eds) The penguins, ecology and management. Surrey Beatty \& Sons, Chipping Norton, p 244-265

Zar JH (1984) Biostatistical analysis. Prentice-Hall, Inc, Englewood Cliffs, NJ

Zasel'sliy VS, Kudrin BD, Poletayey VA, Chechenin SC (1985) Some features of the biology of Electrona carlsbergi Taning (Myctophidae) in the Atlantic sector of the Antarctic. J Ichthyol 25:163-166

Manuscript first recejved: October 11, 1995

Revised version accepted: November 11, 1996 